\title{
Influence of Hypertension and Lifestyle History on Stroke Occurrence Rates in Probolinggo District
}

\author{
Vivin Nur Hafifah \\ Magister of Health Study Program \\ of Institut Ilmu Kesehatan \\ STRADA Indonesia \\ Email: \\ vivinhafifah@gmail.com
}

Received: October 12, 2019

Accepted : February 13, 2020

Published: May 12, 2020

\begin{abstract}
Stroke is a disease of the blood vessels of the brain that is characterized disruption of brain function due to damage or tissue death due to reduction or blockage of blood flow of oxygen to the brain. Blood flow to the brain is reduced due to narrowing, blockage or bleeding. Risk factors important to know in order to avoid and prevent stroke, these factors include hypertension and lifestyle. The purpose of this study untukd Analyzing Lifestyle History Of Hypertension And Stroke incidence rate in Probolinggo. The study design was analytic correlational with cross sectional approach. Collecting data using questionnaires, analysis of data with ordinal regression test at $\alpha=0.05$. The results showed that there is a history of hypertension influence on the incidence rate of stroke in Probolinggo amounted to 9.163 with sig. 0,047 (less than $\alpha(0: 05)$ ), there is the influence of a high-fat diet history against the incidence rate of stroke in Probolinggo amounted to 6.071 with sig. 0,014 (less than $\alpha(0: 05)$ ), there is less physical activity influence on the incidence rate of stroke in Probolinggo amounted to 3.788 with sig. 0,018 (less than $\alpha$ (0:05)), there is the influence of emotional stress on the incidence rate of stroke in Probolinggo amounted to 4,884 with sig. 0,034 (less than $\alpha(0: 05)$ ), there is the effect of smoking on the incidence rate of stroke in Probolinggo amounted to 3.317 with sig. 0,049 (less than $\alpha(0: 05))$. Based on these results, it is suggested that stroke patients to be able to control your blood pressure and can maintain a healthy lifestyle in order to avoid recurrent strokes.
\end{abstract}

Keywords: History of hypertension, Lifestyle, Level Genesis Stroke 


\section{INTRODUCTION}

Technological advances and globalization are the causes of lifestyle changes in every individual, many of whom consume junk food, instant food, alcoholic beverages, smoking, overwork, stress, and lack of exercise (Lili Indrawati, Wening Sari, 2016)

With changes in lifestyle, it has a very large effect on aspects of health. This unhealthy lifestyle can cause a shift in disease, from infectious diseases to non-communicable diseases. One of these disease shifts is stroke (Lili Indrawati, Wening Sari, 2016)

In Indonesia an estimated 500,000 people get a stroke every year, around 25\% die and the rest experience mild or severe disability (Lili Indrawati, Wening Sari, 2016). Based on 2018 Riskesdas data, the prevalence of stroke has increased compared to Riskesdas 2013, which is from $7 \%$ to $10.9 \%$, this increase in prevalence is related to lifestyle including smoking. consumption of alcoholic beverages, physical activity, and not consumption of fruit and vegetables. Since 2013, the prevalence of smoking has increased in adolescents (10-18 years), namely 7.2\% (Riskesdas 2013), 8.8\% (Sirkenas 2016), and $9.1 \%$ (Riskesdas 2018). The proportion of alcoholic beverage consumption from 3\% to 3.3\%, physical activity less also rose from $26.1 \%$ to $33.5 \%$ and $0.8 \%$ consumed excessive alcoholic drinks. Another thing caused by lifestyle is the proportion of consumption of fruits and vegetables less in the population of 5 years, is still very problematic at $95.5 \%(\mathrm{MOH}, 2018)$

Results of preliminary studies conducted by researchers in Probolinggo District on 15 July 2019 there were 141 people (in 2018) and 52 people (from January to May 2019) who suffered a stroke. Of the 10 respondents the researchers met, 70\% were due to lifestyle factors (some of which were caused by cholesterol, hypertension, lack of exercise, and diabetes mellitus).

The results of the study (Alchuriyah \& Wahjuni, 2016) state that stroke risk factors are caused by hypertension $85 \%$, not obesity $53.3 \%$, increase in cholesterol level $58.3 \%$, and diabetes mellitus $53.3 \%$. (Putrianti, 2015) in her research in Semarang stated that lifestyle factors related to the incidence of stroke at a young age are eating habits of sodium-source food, eating habits of fiber-source foods, physical activity, and stress levels. (Glen Y. C. R. Kabi, Rizal Tumewah, 2015), also mentioned in his research in Neurology inpatients Prof. RSUP Dr. R. D. Kandou Manado period July 2012 - June 2013 that patients who often have a stroke are patients aged 51-65 years with patients who have a history of hypertension. In research (Patricia, Kembuan, \& Tumboimbela, 2015) showed that the highest percentage of causes of stroke is hypertension (74.70\%).

Stroke is a nervous system disorder that occurs suddenly caused by disorders of the blood vessels of the brain, the disorder can be in the form of blocked blood vessels or rupture of blood vessels of the brain. In other words, the brain which is supposed to get a supply of oxygen and nutrients is disrupted so that it will cause the death of nerve cells (neurons), so that the disruption of brain function will cause stroke symptoms (Rizaldy Pinzon, 2010)

When a stroke occurs, then the brain function will be disrupted, body movements can no longer function as before, memory and perception of a state decreases, and even abilities that were previously able to be done alone disappear altogether if the stroke has developed more severely ((Lanny Lingga, 2013)

Since stroke can strike suddenly and can cause disability and even death, prevention is an effective way to avoid a stroke. Prevention that can be done is to know the risk factors for stroke, check blood pressure, check whether there is heart disease, controlling diabetes, lowering cholesterol levels, stopping smoking, maintaining diet, avoiding stress and exercising diligently (Lili Indrawati, Wening Sari, 2016). From the problems mentioned above, the researchers want to analyze the history of hypertension and lifestyle on the incidence of stroke in Probolinggo.

\section{METHODS}

In this study, researchers used a quantitative design with a cross sectional approach that is analyzing a problem with detailed boundaries, having in-depth data retrieval, and including various sources of information. This study will analyze the effect of hypertension history factors and lifestyle factors on stroke prevalence in Probolinggo district. The number of samples of this study were 131 informants with a sampling technique using cluster random sampling. Data analysis using Ordinal Regression test. 
RESULTS

\begin{tabular}{|c|c|c|c|c|c|c|c|c|}
\hline \multicolumn{9}{|c|}{ Parameter Estimates } \\
\hline & & \multirow{2}{*}{ 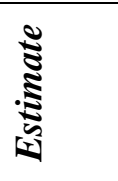 } & \multirow{2}{*}{ के } & \multirow{2}{*}{$\sqrt{\Sigma}$} & \multirow{2}{*}{$\grave{a}$} & \multirow{2}{*}{$\dot{0}$} & \multicolumn{2}{|c|}{$\begin{array}{c}95 \% \text { Confidence } \\
\text { Interval }\end{array}$} \\
\hline & & & & & & & $\begin{array}{l}\text { Lower } \\
\text { Bound }\end{array}$ & $\begin{array}{c}\text { Upper } \\
\text { Bound }\end{array}$ \\
\hline $\begin{array}{l}\text { Thres } \\
\text { Hold }\end{array}$ & $\begin{array}{l}\text { Stroke } \\
\text { Incidence } \\
\text { Rate }\end{array}$ & 45.652 & 1453.053 & .001 & 1 & .975 & -2802.280 & 2893.584 \\
\hline \multirow[t]{5}{*}{ Location } & $\begin{array}{l}\text { History of } \\
\text { Hypertensi } \\
\text { on }\end{array}$ & 15.538 & 1453.016 & 9.163 & 1 & .047 & -2832.322 & 2863.397 \\
\hline & $\begin{array}{l}\text { History of a } \\
\text { High-Fat } \\
\text { Diet }\end{array}$ & .744 & .302 & 6.071 & 1 & .014 & .152 & 1.336 \\
\hline & $\begin{array}{l}\text { Less } \\
\text { Physical } \\
\text { Activity }\end{array}$ & 1.666 & 1.246 & 3.788 & 1 & .018 & -.776 & 4.109 \\
\hline & $\begin{array}{l}\text { Emotional } \\
\text { stress }\end{array}$ & .176 & .187 & 4.884 & 1 & .034 & -.191 & .544 \\
\hline & $\begin{array}{l}\text { Smoking } \\
\text { habit }\end{array}$ & 1.388 & .762 & 3.317 & 1 & .049 & -.106 & 2.882 \\
\hline
\end{tabular}

1. There is an Influence of History of Hypertension on Stroke Occurrence Rates in Probolinggo District (Puskesmas Maron, Krejengan, and Glagah)

2. There is an Effect of a High Fat Diet History on the Stroke Incidence Rate in Probolinggo District (Puskesmas Maron, Krejengan, and Glagah)

3. There Is Less Effect of Physical Activity on Stroke Occurrence Rates in Probolinggo District (Puskesmas Maron, Krejengan, and Glagah)

4. There is an Influence of Emotional Stress on Stroke Occurrence in Probolinggo District (Puskesmas Maron, Krejengan, and Glagah)

5. There is an influence of smoking habits on the incidence rate of stroke in Probolinggo District (Puskesmas Maron, Krejengan, and Glagah)

6. History of hypertension has the most dominant tendency in influencing the incidence of stroke, especially ischemic stroke in Probolinggo District (Puskesmas Maron, Krejengan, and Glagah)

\section{DISCUSSION}

Influence of History of Hypertension on Stroke Occurrence Rates in Probolinggo District (Puskesmas Maron, Krejengan, and Glagah)

The results of ordinal regression analysis of hypertensive history variables indicate sig. 0.047 (less than $\alpha(0.05)$ ), so $\mathrm{H} 0$ is rejected and $\mathrm{Ha}$ is accepted, which means there is an influence of hypertension history factors on the incidence of stroke in Probolinggo District (Puskesmas Maron, Krejengan, and Glagah). This is in line with research (Patricia, Kembuan, \& Tumboimbela, 2015) which found that the biggest cause of stroke is hypertension (74.70\%).

The study (Glen Y. C. R. Kabi, Rizal Tumewah, 2015) also mentioned that patients who often had a stroke were patients who had a history of hypertension. High blood pressure (hypertension) is also called a silent killer because in most cases, it does not show any symptoms. Stroke is one of the causes caused by hypertension, stroke can occur due to high pressure bleeding in the brain, or due to an embolus that is detached from non-brain vessels exposed to high pressure. Stroke can occur in chronic hypertension if the arteries that blood the brain experience hypertrophy and thickened, so that blood flow to the areas that are affected is reduced. Brain arteries that experience atherosclerosis can be weakened thereby increasing the possibility of aneurysm formation (Dr. Alfeus Manuntung, S.Kep., 2018).

Various studies have proven that controlling hypertension will reduce the incidence of stroke. The results of 61 long-term studies show that every increase in blood pressure of 20/10 $\mathrm{mmHg}$ (starting 
with blood pressure $115 / 75 \mathrm{mmHg}$ ) will increase stroke mortality twice. While a decrease of $2 \mathrm{mmHg}$ systolic pressure can cause a reduction in stroke mortality by $10 \%$ (Yueniwati, 2015).

The results showed there was a significant effect between hypertension and stroke. Hypertension is one of the main factors causing a person to have a stroke, based on the results of the study it was found that respondents who had a stroke were caused by a history of hypertension, which was 120 respondents (92\%). Data in Maron, Krejengan and Glagah hypertension is the highest disease in the region, this is because respondents in the work area in cooking food prefer to add more salt in their food, according to them the food does not taste if the salt is only slightly, the distance between the region and the beach $\pm 8 \mathrm{~km}$ is also a factor that makes them easier to get salt.

\section{Effects of High Fat Diet History on Stroke Occurrence Rates in Probolinggo District (Maron, Krejengan, and Glagah Health Center)}

The results of ordinal regression analysis of dietary variables high in fat showed sig. 0.014 (less than $\alpha(0.05)$ ), so $\mathrm{H} 0$ is rejected and $\mathrm{Ha}$ is accepted which means there is a significant influence of a high-fat diet history on the incidence of stroke in Probolinggo District (Puskesmas Maron, Krejengan, and Glagah).

This is in line with research (Alchuriyah \& Wahjuni, 2016), the results of the study of the majority of respondents experienced an increase in cholesterol levels in the borderline high and high categories, an increase in cholesterol levels due to an unhealthy patient lifestyle that is eating patterns and lifestyles that consume a lot of foods that have high cholesterol and saturated fat.

A high-fat diet can increase the risk of stroke. Cholesterol is a fat which is very important in the formation of cell walls in the human and animal bodies. Cholesterol is also found in human blood circulation. Cholesterol found in the human body comes from the food consumed and from the formation by the liver. Cholesterol derived from food is found in meat, poultry, fish (shrimp and shellfish), dairy products (sweetened condensed milk, fatty milk powder, or full cream and ice cream), offal such as intestines, tripe, gizzard, spleen, kidney, heart and lungs (I Made C. Irawan, 2013).

If the intake of cholesterol in food that enters the body is too high, the amount of cholesterol in the blood will increase. Cholesterol does not dissolve in blood fluids so that the process of transportation throughout the body needs to be packaged with protein into particles called lipoproteins. Lipoprotein many types, usually in laboratory tests there is an examination of levels of fat profiles consisting of total cholesterol, Low Density Lipoprotein (LDL), and triglycerides. LDL is known as bad cholesterol, because high LDL levels can cause deposition of cholesterol in the arteries which triggers blood vessel blockage (atherosclerosis), narrow blood vessels that disrupt blood supply to the brain called ischemic stroke (Yueniwati, 2015).

The results showed that stroke sufferers at the Maron, Krejengan and Glagah health centers were caused by a history of a high-fat diet of 104 respondents (79.4\%). This is because the respondents like to consume foods that contain coconut milk, where foods that are coconut milk are very risky to increase cholesterol levels. Maron, Krejengan and Glagah areas, besides being close to the sea, are also at the foot of the mountain, so to consume coconut milk, they sometimes do not need to buy, just take it from the yard. For this reason, awareness is needed from them to be able to maintain their diet in order to control their cholesterol levels, and the role of health workers is needed to carry out health promotion, especially regarding stroke,

\section{Effect of Less Physical Activity on Stroke Occurrence in Probolinggo District (Puskesmas Maron, Krejengan, and Glagah)}

The results of ordinal regression analysis of physical activity variables show less sig. 0.018 (less than $\alpha(0.05)$ ), which means there is a significant effect of less physical activity on the incidence of stroke in Probolinggo District (Puskesmas Maron, Krejengan, and Glagah).

Less physical activity makes blood circulation less smooth. Though blood carries oxygen and nutrients for the body's cells. In addition, lack of activity can cause obesity which is a risk factor for stroke. Sports and activities can reduce the risk of stroke (Li Partic, 2014).

Physical activity is beneficial to improve balance, optimize growth and development, reduce the risk of premature death, improve the work of the heart and lung muscles. Physical activity is also 
beneficial in increasing the body's metabolism, controlling stress, reducing anxiety and depression. Those who often do physical activities, muscles, bones and joints will be strong and flexible. Physical activity also benefits in reducing the risk of high blood pressure (Mediani Dyah Natalia, 2016)

Improvement of activities related to these things can actually reduce $80 \%$ of noncommunicable diseases such as stroke which contributes to the world's largest mortality (Hermien Nugraheni, Tri Wiyatini, 2018)

The results showed that 24 respondents $(18.3 \%)$ with mild activity. This is because the activities of the respondents only stay at home, families also limit their activities due to age (over 65 years), they only watch TV and do ADL. For this reason, physical activity is needed, such as relaxing and sweeping walks, to avoid stroke because physical activity is beneficial to improve balance, optimize growth and development, reduce the risk of premature death, improve the work of the heart and lung muscles, increase body metabolism, control stress, reduce anxiety and depression. Those who often do physical activities, muscles, bones and joints will be strong and flexible. Physical activity also provides benefits in reducing the risk of high blood pressure.

\section{The Effect of Emotional Stress On Stroke Occurrence Rate in Probolinggo District (Maron, Krejengan, and Glagah Health Center)}

The results of ordinal regression analysis of emotional stress variables show sig. 0.034 (less than $\alpha(0.05)$ ), which means there is a significant influence of emotional stress on the incidence of stroke in Probolinggo District (Puskesmas Maron, Krejengan, and Glagah). This study is almost the same as the study conducted by (Muhammad Saleh, 2014), found a correlation value (r) stress level with hypertension degree 0.486 with moderate strength, a significance value of $0,000(p<0.05)$ and positive direction means higher levels of stress the higher the degree of hypertension.

Someone who often experiences emotional stress can affect his physical condition, stress can stimulate the body to release hormones that affect the heart and blood vessels (Lili Indrawati, Wening Sari, 2016). In a state of stress the body produces the hormones cortisol and adrenaline which contribute to the process of atherosclerosis. This is due, both of these hormones can increase platelet count and cholesterol production. Cortisol and adrenaline can also damage the cells lining the arteries making it easier for fat tissue to be buried inside the artery walls (Yueniwati, 2015).

When the cortisol hormone rises, the immune system decreases so people get sick more easily when they're upset. Increase in the hormone cortisol causes adrenaline fluctuations. Adrenaline rise and fall makes the blood rhythm unstable, eventually causing damage to blood vessel endothelium. When there are damaged cells, the body automatically repairs them by growing new tissue. However, this new network can grow without smoothness. When cholesterol and fat content pass, it will be involved in the new tissue that was not smooth. Over time the new tissue that is not smooth becomes large, and eventually causes blockage of blood vessels in the brain, and an ischemic stroke (Sulaiman, 2018)

Stress also triggers hypertension, which when stressed the body will increase sympathetic nerve activity. When the sympathetic nerve increases its activity, blood pressure will increase intermittently (erratic) so that it will cause a stroke (Ns. Alfeus Menuntung, S.Kep., 2018)

The results showed that stroke sufferers at the Maron, Krejengan and Glagah Puskemas were caused by mild stress namely 48 respondents $(36.6 \%)$ and moderate stress 8 respondents $(6.1 \%)$. This process does not take place immediately, cell damage causing clogging can take months to years. The risk of blockage can occur early if the stress experienced is not handled properly. The more often a person experiences stress, and poor stress management, can accelerate the occurrence of blockages. For this reason the importance of stress management is needed, not only for the soul, but also for the brain.

\section{Effects of Smoking Habits on Stroke Occurrence in Probolinggo District (Puskesmas Maron, Krejengan, and Glagah)}

The results of ordinal regression analysis of smoking habit variables show sig. 0.049 (less than $\alpha(0.05)$ ), which means there is a significant influence of smoking habits on the incidence of stroke in Probolinggo District (Puskesmas Maron, Krejengan, and Glagah).

This is consistent with research (Iskandar, 2018) where smoking has an influence on the incidence of ischemic stroke at less than 45 years of age $(\mathrm{p}=0.019 ; \mathrm{OR}=3.859 ; 95 \% \mathrm{CI}=1,250$ 11,911). The risk of ischemic stroke in people who have a smoking habit is 3.859 times greater than for people who don't smoke. 
Smoking is one of the significant factors to increase the risk of stroke. People who have the habit of smoking tend to be more at risk for stroke than people who don't smoke. This is caused by toxic chemicals in cigarettes such as nicotine and carbon monoxide which can damage the endothelial lining of arteries, increase blood pressure, and cause cardiovascular damage through various body mechanisms. Smoking is also associated with increasing fibrinogen levels, platelet aggregation, decreasing HDL and increasing hematocrit which can accelerate the process of atherosclerosis which is a risk factor for stroke (Yueniwati, 2015).

Smoking is a potential risk factor for ischemic stroke and bleeding due to rupture of blood vessels in the posterior region of the brain. Some substances contained in cigarettes trigger blood clots, this frozen blood flow prevents blood from flowing into the brain smoothly and results in a blockage which is one of the reasons a person experiences stroke symptoms (Fernando, 2018).

In a cigarette contained more than 4,000 types of chemicals that are divided into solid materials and gas components. Three of these chemicals are very dangerous, namely nicotine, tar, and carbon monoxide. Nicotine is a chemical that is addictive and affects nerves and blood circulation. Nicotine can cause blood vessels to narrow and harden, and increase blood pressure and heart rate. Narrowing of blood vessels and increased blood pressure are risk factors for stroke. Meanwhile, carbon monoxide in cigarettes can reduce the supply of oxygen carried in the bloodstream. Carbon monoxide can also cause fat blockage in the arteries. These conditions can make blood vessels burst suddenly, and cause bleeding in the brain, known as hemorrhagic stroke. Carbon monoxide can also reduce levels of good fats (HDL) in the body, so levels of bad fats (LDL) will increase. This condition can cause a buildup of bad fats in blood vessels, thereby increasing the risk of stroke (Dr. Dyah Novita Anggraini, 2016)

The results of the study showed that stroke sufferers in the working area of Maron, Krejengan and Glagah Puskemas were caused because 18 respondents (13.7\%) were light smokers, this was because respondents were calmer in their minds when consuming cigarettes, and besides that Probolinggo was the largest region in Indonesia as a producer of tobacco. To stop smoking is very difficult for them, so that self-awareness and intention to stop smoking are needed because the area of Probolinggo, especially Krejengan and Glagah, is the main crop of tobacco.

\section{History of Hypertension which has the most influence on the incidence of stroke in Probolinggo District (Puskesmas Maron, Krejengan, and Glagah)}

Based on Wald's value, it can be concluded that the history of hypertension has the most dominant tendency in influencing the incidence of stroke, which is 9,163 , which means the history of hypertension has a great influence on the incidence rate of stroke, which is 9,163 times higher than other factors.

Blood pressure is one factor that must be considered in the event of a stroke. High blood pressure or hypertension is a major factor, both in ischemic and hemorrhagic strokes. This is because hypertension triggers atherosclerosis due to high pressure. As a result, it encourages Low Density Lipoprotein (LDL) cholesterol to more easily enter the intestinal lumen of blood vessels and reduce the elasticity of these blood vessels. (Yueniwati, 2015). So that it can disrupt blood flow to brain tissue (Lili Indrawati, Wening Sari, 2016).

The results of this study the majority of respondents who experienced an ischemic stroke caused by hypertension. This is because respondents prefer to consume excessive salt or also because of an unbalanced diet (high fat diet), genetic factors and stress are also factors they are exposed to hypertension. For that a healthy lifestyle they really need is by reducing the consumption of salt and saturated fat, doing regular exercise, stopping smoking, maintaining a stable body weight, and avoiding stress. If a healthy lifestyle change is unsuccessful, antihypertensive medication is needed.

\section{CONCLUSION}

1. There is an influence of hypertension history on the incidence rate of stroke in Probolinggo District (Puskesmas Maron, Krejengan, and Glagah)

2. There is an Effect of High Fat Diet History on Stroke Occurrence Rates in Probolinggo District (Puskesmas Maron, Krejengan, and Glagah)

3. There Is Less Effect of Physical Activity on Stroke Occurrence in Probolinggo District (Puskesmas Maron, Krejengan, and Glagah) 
4. There is an Influence of Emotional Stress on Stroke Occurrence in Probolinggo District (Puskesmas Maron, Krejengan and Glagah)

5. There Are Effects of Smoking Habits on the Occurrence of Stroke in Probolinggo District (Puskesmas Maron, Krejengan, and Glagah)

6. History of hypertension has the most dominant tendency in influencing the incidence of stroke, especially ischemic stroke in Probolinggo District (Puskesmas Maron, Krejengan, and Glagah)

\section{REFERENCES}

A. Husein Fattah. (2017). Kepuasan Kerja \& Kinerja Pegawai Budaya Organisasi, Perilaku Pemimpin, Dan Efikasi Diri (1st ed.; Ratu Wardarita, ed.). Yogyakarta: Elmatera.

Alchuriyah, S., \& Wahjuni, C. U. (2016). Faktor Risiko Kejadian Stroke Usia Muda Pada Pasien Rumah Sakit Brawijaya Surabaya. Jurnal Berkala Epidemiologi, 4(1), 62-73. https://doi.org/10.20473/jbe.v4i1.62-73

Alexander Lucas Slamet Riyadi. (2016). Ilmu Kesehatan Masyarakat (C. J. D. Yudhiakuri Sincihu, Steven, ed.). Yogyakarta: ANDI.

Anugrah. (2013). Hubungan Obesitas, Aktivitas Fisik, Dan Kebiasaan Merokok dengan Penyakit Diabetes Melitus Tipe 2 pada Pasien Rawat Jalan Rumah Sakit dr. Wahidin Sudirohusodo Makassar. Kesehatan, 1 Nomor 6.

Arikunto. (2016). Prosedur Penelitian Suatu Pendekatan Praktik. Jakarta: Rineka Cipta.

Bustan. (2010). Epidemiologi Penyakit Tidak Menular. Jakarta: Pt Rineka Cipta.

Depkes. (2018). Potret Sehat Indonesia dari Riskesdas 2018. http://www.depkes.go.id/article/view/18110200003/potret-sehat-indonesia-dari-riskesdas2018.html.

Dong, L., Sánchez, B. N., Skolarus, L. E., Morgenstern, L. B., \& Lisabeth, L. D. (2018). Ethnic Differences in Prevalence of Post-stroke Depression. Circulation: Cardiovascular Quality and Outcomes, 11(2), 1-11. https://doi.org/10.1161/Circoutcomes.117.004222

dr. Dyah Novita Anggraini. (2016, September 1). Benarkah Merokok Dapat Tingkatkan Risiko Stroke? Https://Www.Klikdokter.Com/Info-Sehat/Read/2664638/Benarkah-Merokok-Dapat-TingkatkanRisiko-Stroke.

Fernando, S. (2018). Bad Habit: Ketika Kata Sudah Biasa Itu ternyata Berbahaya (1st ed.; Yulian Masda, ed.). Jakarta: PT Elex Media Komputindo Kelompok Gramedia.

Ghani, L., Mihardja, L. K., \& Delima, D. (2016). Faktor Risiko Dominan Penderita Stroke di Indonesia. Buletin Penelitian Kesehatan, 44(1), 49-58. https://doi.org/10.22435/bpk.v44i1.4949.49-58

Glen Y. C. R. Kabi, Rizal Tumewah. (2015). Gambaran Faktor Risiko Pada Penderita Stroke Iskemik Yang Dirawat Inap Neurologi Rsup Prof. Dr. R. D. Kandou Manado Periode Juli 2012 - Juni 2013. E-CliniC, 3(1), 1-6.

Hermien Nugraheni, Tri Wiyatini, I. W. (2018). Kesehatan Masyarakat Dalam Determinan Sosial Budaya (Pertama). Yogyakarta: Penerbit Deepublish (Grup Penerbitan CV Budi Utama).

I Made C. Irawan. (2013). Berbagai Tips Hidup Sehat Dengan Cara Sederhana 2 (2nd ed.). Jakarta Selatan: Noura Books (PT Mizan Publika).

Iskandar, A. (2018). Kejadian Stroke Iskemik Pada Usia Kurang Dari 45 Tahun ( Studi Di BLUD RSUD Cut Nyak Dhien Meulaboh Kabupaten Aceh Barat Provinsi Aceh) Naskah Publikasi Arif Iskandar.

Lanny Lingga. (2012). Bebas Hipertensi Tanpa Obat (Pertama). Jakarta Selatan: PT AgroMedia Pustaka.

Lanny Lingga. (2013). All About Stroke Hidup Sebelum dan Pasca Stroke. Jakarta: PT Elex Media Komputindo Kelompok Gramedia.

Li Partic. (2014). Perisai Segala Penyakit. Jakarta: PT Elex Media Komputindo Kelompok Gramedia.

Lili Indrawati, Wening Sari, C. S. D. (2016). Care Your Self Stroke : Cegah Dan Obati Sendiri (1st ed.; S. K. Indriani, ed.). Jakarta: Plus (Penebar Swadaya Grup).

Mediani Dyah Natalia. (2016). Kurang Aktivitas Fisik Bisa Sebabkan Stroke dan Penyakit Jantung. Https://Www.Solopos.Com/Kurang-Aktivitas-Fisik-Bisa-Sebabkan-Stroke-Dan-PenyakitJantung-758434.

Muhammad Saleh. (2014). Hubungan Tingkat Stres Dengan Derajat Hipertensi Pada Pasien Hipertensi Di Wilayah Kerja Puskesmas Andalas Padang Tahun 2014. Ners Jurnal Keperawatan, 10, 166- 
175.

Muttaqin, A. (2011). Asuhan Keperawatan Klien Dengan Gangguan Sistem persarafan (Aulia Novianty, ed.). Jakarta: Salemba Medika.

Ns. Alfeus Menuntung, S.Kep., M. K. (2018). Terapi Perilaku Kognitif Pada Pasien Hipertensi. Malang: Wineka Media.

Nurmalina. (2011). Pencegahan \& Manajemen Obesitas. Bandung: Elex Media Komputindo.

Nursalam. (2015). Metodologi Penelitian Ilmu Keperawatan:Pendekatan Praktis (4th ed.; P. P. L. Aklia Suslia, ed.). Jakarta: Salemba Medika.

Nursalam. (2016). Metodologi Penelitian Ilmu Keperawatan: Pendekatan Praktis (4th ed.). Jakarta: Salemba Medika.

P2PTM Kemenkes RI. (2018, May). Faktor Resiko Hipertensi. Http://Www.P2ptm.Kemkes.Go.Id/Infographic-P2ptm/Hipertensi-Penyakit-Jantung-DanPembuluh-Darah/Page/18/Faktor-Risiko-Hipertensi.

Padir Sensoz, N., Turk Boru, U., Boluk, C., Bilgis, A., Oztop Cakmak, O., Duman, A., \& Tasdemir, M. (2018). Stroke epidemiology in Karabük city Turkey: Community based study. ENeurologicalSci, 10(December 2017), 12-15. https://doi.org/10.1016/j.ensci.2017.12.003

Patricia, H., Kembuan, M. A. H. N., \& Tumboimbela, M. J. (2015). Karakteristik Penderita Stroke Iskemik Yang Di Rawat InaP Di RSUP PROF . DR . R . D . Kandou Manado Kandidat Skripsi Fakultas Kedokteran Universitas Sam Ratulangi Manado Berdasarkan definisi WHO ( World Health Organization ) stroke adalah manifestasi klin. 3(April).

Pendlebury, S. T., \& Rothwell, P. M. (2019). Incidence and prevalence of dementia associated with transient ischaemic attack and stroke: analysis of the population-based Oxford Vascular Study. The Lancet Neurology, 18(3), 248-258. https://doi.org/10.1016/S1474-4422(18)30442-3

Putrianti, I. (2015). Hubungan Antara Gaya Hidup dengan Kejadian Stroke Usia Dewasa Muda (1840 Tahun) di Kota Semarang. 95-107.

Rahajeng Ekowati. (2011). Upaya Pengendalian Penyakit Tidak Menular di Indonesia. Buletin Penyakit Tidak Menular. Jakarta: Semester 2 2012. pp 23 - 28.

Rizaldy Pinzon, L. A. (2010). Awas Strok!Pengertian, Gejala,Tindakan, Perawatan, dan Pencegahan (I). Yogyakarta: CV Andi Offset (Penerbit ANDI).

Setyopranoto, I., Bayuangga, H. F., Panggabean, A. S., Alifaningdyah, S., Lazuardi, L., Dewi, F. S. T., \& Malueka, R. G. (2019). Prevalence of stroke and associated risk factors in sleman district of Yogyakarta Special Region, Indonesia. Stroke Research and Treatment, 2019. https://doi.org/10.1155/2019/2642458

Shindler-Itskovitch, T., Chodick, G., Shalev, V., \& Muhsen, K. (2019). Helicobacter pylori infection and prevalence of stroke. Helicobacter, 24(1), 1-7. https://doi.org/10.1111/hel.12553

Soekidjo Notoatmodjo. (2010). Metodoloogi Penelitian Kesehatan. Jakarta: Rineka Cipta.

Soekidjo Notoatmojo. (2010). Metodologi Penelitian Kesehatan. Jakarta: Rineka Cipta.

Sugiyono. (2010). Metode Penelitian Pendidikan Pendekatan Kuantitatif, kualitatif, dan R\&D. Bandung: Alfabeta.

Sugiyono. (2014). Metode Penelitian Pendidikan Pendekatan Kuantitatif dan R\&D. Bandung: Alfabeta.

Sugiyono. (2016). Metode Penelitian Kuantitatif, Kualitatif dan R\&D. Bandung: PT Alfabet.

Sulaiman, M. R. (2018, April 8). Begini Cara Stres Rusak Otak Hingga Sebabkan Stroke. Https://Health.Detik.Com/Berita-Detikhealth/d-3959607/Begini-Cara-Stres-Rusak-OtakHingga-Sebabkan-Stroke.

Suyanto. (2017). Description Of Diabetes Mellitus And Hypertension In Stroke Patients Keywords: Diabetic Mellitus, Hypertention, Stroke Pendahuluan. Rnal Keperawatan Volume 10 No 2, Hal 125 - 129, Maret 2018 Jurnal Keperawatan Volume 10 No 2, Hal 125 - 129, September 2018, 10, $125-129$.

Tim Navari. (2015). 1001 Makanan Sehat. Jakarta: PT Elex Media Komputindo Kelompok Gramedia. Wagiran. (2019). Metodologi Penelitian Pendidikan : Teori Dan Implementasi (1st ed.). Yogyakarta: Deepublish.

Yueniwati, Y. (2015). Deteksi Dini Stroke Iskemia Dengan Pemeriksaan Ultrasonografi Vaskular dan Variasi Genetika (1st ed.; R. Erlangga, ed.). Malang: UB Press. 